\title{
Rancang Bangun Sistem Presensi Mahasiswa Berbasis Fingerprint Client Server
}

\author{
Decki Noor Cahyadi ${ }^{1}$, Tenia Wahyuningrum ${ }^{2}$, Irwan Susanto ${ }^{3}$ \\ ${ }^{1,2,3}$ Sekolah Tinggi Teknologi Telematika Telkom Purwokerto \\ Jl. DI Panjaitan 128 Purwokerto \\ 1d309015_decki@yahoo.com, ${ }^{2}$ tenia@st3telkom.ac.id, ${ }^{3}$ irwan@st3telkom.ac.id
}

\begin{abstract}
Abstrak - Presensi mahasiswa merupakan salah satu peran penting dalam kegiatan belajar dan mengajar. Sistem Presensi melalui SIMAK di ST3 Telkom memiliki beberapa kekurangan, yaitu memerlukan waktu khusus untuk memanggil mahasiswa satu persatu, juga memiliki celah kecurangan, jika dosen yang bersangkutan tidak mengenali wajah mahasiswa, sehingga ada kemungkinan mahasiswa mengaku sebagai mahasiswa lain. Berdasarkan hasil analisa, ditawarkan sebuah inovasi baru untuk Sistem Presensi menggunakan fingerprint berbasis client server. Dalam pembangunan Sistem Presensi ini menggunakan metode pengembangan sistem waterfall, DBMS Microsoft Access dan Visual Basic 6.0 sebagai bahasa pemrogramannya. Hasil pengujian menunjukkan sistem informasi presensi sudah dapat berjalan dengan baik. Output sesuai dengan rancangan yang telah dibuat.
\end{abstract}

Kata Kunci : Presensi Mahasiswa, Finger print, Client Server, Microsoft Access, Visual Basic 6.0

\section{PENDAHULUAN}

Pemanfaatan teknologi informasi pada era globalisasi sekarang ini tidak dapat dipisahkan dari kehidupan sehari-hari.Terutama dibidang teknologi informasi yang semakin berkembang seiring dengan kebutuhan user untuk memperoleh suatu karya yang maksimal serta memperoleh kemudahan dalam segala aktivitas untuk mencapai suatu tujuan.Presensi mahasiswa merupakan salah satu peran penting dalam kegiatan belajar dan mengajar, disamping itu presensi merupakan informasi tentang bagaimana kedisipinan mahasiswa dalam mengikuti kegiatan belajar dan mengajar.

Sistem Informasi Manajemen Akademik (SIMAK) telah memiliki fasilitas presensi mahasiswa secara online. Sistem pengambilan data presensi dilakukan oleh dosen yang bersangkutan dengan cara memanggil mahasiswa satu persatu dan dosen menekan tombol hadir, ijin, alpha, dan sakit. Dengan sistem tersebut, maka akan memakan waktu sekitar 10-15 menit, sehingga cukup mengurangi waktu efektif perkuliahan. Selain itu, presensi mahasiswa online membutuhkan koneksi internet yang selalu terjaga kondisinya. Bila pada saat kuiah berlangsung, internet mati, maka presensi tidak dapat dilakukan. Presensi mahasiswa secara online juga terdapat celahcelah kecurangan, jika dosen tidak hapal wajah mahasiswa, sehingga ada kemungkinan mahasiswa mengaku sebagai mahasiswa lain.

Untuk itu diperlukan sistem presensi yang lebih akurat, efisien, dan tidak membutuhkan koneksi internet, melalui suatu perangkat lunak yang dapat meningkatkan keakuratan untuk mengambil data kehadiran mahasiswa. Salah satu cara tersebut dengan menerapkan presensi mahasiswa dengan menggunakan finger print dengan bantuan software Visual Basic 6.0, database yang digunakan adalah Microsoft Access.

Fingerprint atau sidik jari merupakan identitas pribadi yang digunakan untuk mengenali seseorang. Dimana setiap orang memiliki sidik jari yang berbeda - beda yang meruapakan penanda alami. Karena keunikannya, sidik jari dipakai oleh pihak berwajib dalam penyelidikan kasus kejahatan. Karakteristik yang dimiliki oleh sidik jari yaitu guratan - guratan yang terdapat pada sidik jari yang melekat pada setiap orang seumur hidup. Sidik jari seseorang tidak akan berubah seumur hidup, kecuali terjadinya suatu kecelakaan yang serius yang dapat mengubah pola sidik jari yang ada[3].

Dalam pembuatan aplikasi ini, diperlukan sebuah database untuk menyimpan data, Microsoft Access dipilih sebagai Database Management System, yang menyimpan file dalam sebuah berkas dengan ekstensi [.mdb]. Didalam berkas inilah semua objek yang terkait dengan database termasuk semua tabel, disimpan pada istilah kolom yang biasa dipakai pada basisdata relasional disebut Field dan baris biasa disebut Record [3]. Bahasa pemrograman yang digunakan untuk membuat aplikasi ini adalah Visual Basic 6.0 dimana program dilengkapi dengan aplikasi Graphical User Interface (GUI). Program juga memungkinkan pengguna komputer dapat berkomunikasi menggunakan media grafik atau gambar dengan komputer tersebut. Microsoft Visual Basic 6.0 menyediakan fasilitas yang dapat menyusun sebuah program dengan memasang objek - objek grafis dalam sebuah form[1]. 
Teknologi finger print adalah alat untuk memudahkan para mahasiswa dan juga menghindari adanya kecurangan karena finger printpresensi tersebut tidak dapat dimanipulasi. Finger print telah terbukti cukup akurat, aman, mudah dan nyaman untuk dipakai sebagai identifikasi bila dibandingkan dengan sistem lainnya. Sistem presensi ini menggunakan jaringan client server, yaitu terdapat sebuah komputer yang bertindak sebagai serveruntuk menyimpan data presensi dan client yang diletakkan di sisi user.

\section{METODOLOGI}

Metode pengembangan sistem yang digunakan dalam Sistem Presensi Mahasiswa ini adalah Model System Development Life Cycle (SDLC) sering disebut model air terjun (waterfall) menyediakan model pendekatan alur hidup klasik. Model air terjun menyediakan pendekatan alur hidup perangkat lunak secara sekuensial atau terurut dimulai dari analisa, desain, pengkodean, pengujian dan pemeliharaan[4].

Pressman membagi SDLC menjadi 4 tahap seperti gambar berikut :

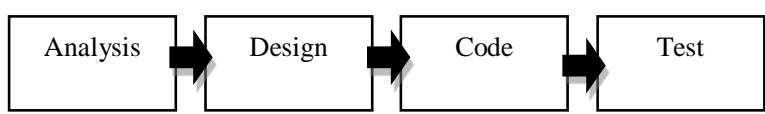

Gambar 1. Model SDLC menurut Pressman [2]

Dalam SDLC, persyaratan harus dipahami dengan baik. Persyaratan kebutuhan pengguna dilakukan dengan metode kuesioner dan pengamatan.Analisa kebutuhan ini merupakan salah satu tahap yang mendasar pembuatan sistem aplikasi.

\section{PERANCANGAN SISTEM}

\section{A. Alat yang dibutuhkan}

Alat pendukung tersebut berguna sebagai media dalam pembuatan sebuah program aplikasi. Alat pendukung yang digunakan untuk perancangan sistem informasi presensi ini yaitu :

a. Hardware yaitu Laptop/PC dan Fingerprint device b. Software yaitu Visual Basic 6.0, Microsoft Access.

\section{B. Data Flow Diagram (DFD)}

Adapun penggambaran DFD dari sistem presensi mahasiswa menggunakan finger print seperti ditunjukkan pada Gambar 2.

Pada gambar 2, user dosen memasukkan tanggal, jam dan materi pada form presensi yang juga dapat digunakan sebagai Berita Acara Perkuliahan. Mahasiswa memasukkan sidik jari sebagai trigger untuk presensi. Informasi presensi diolah aplikasi untuk ditampilkan di kedua sisi user, dosen dan mahasiswa.

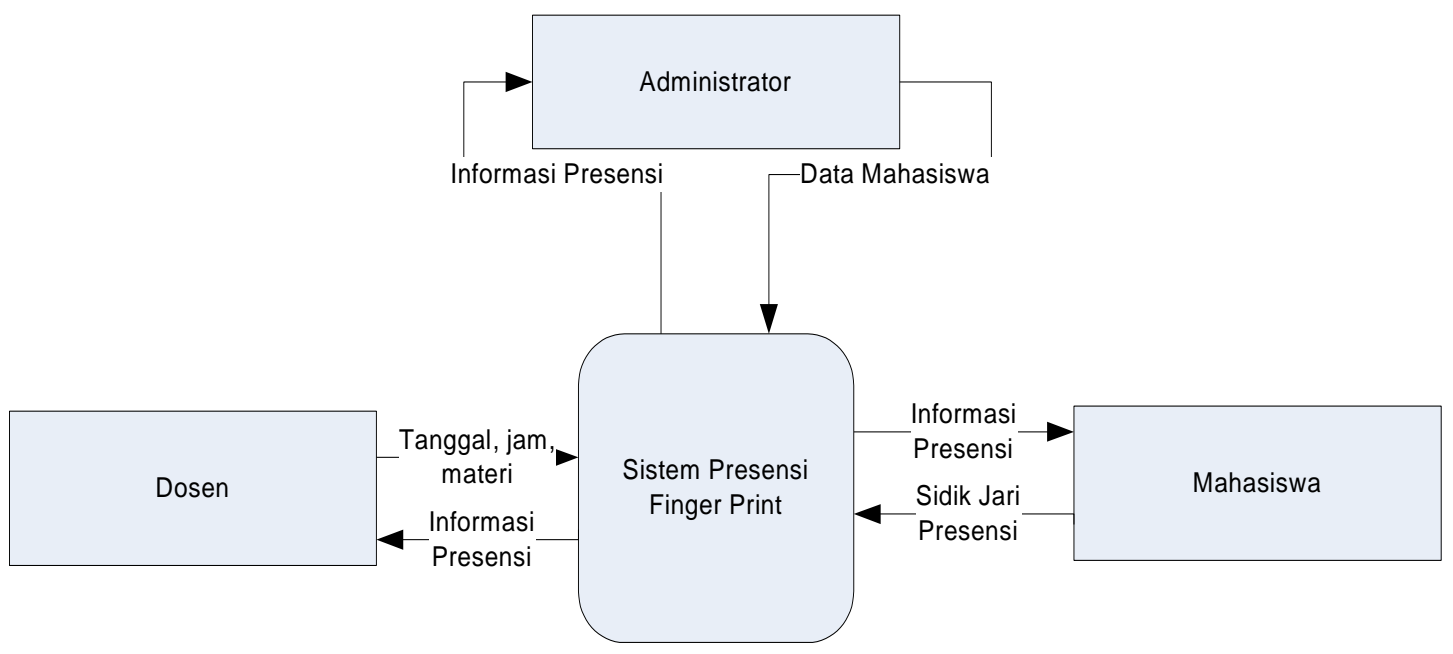

Gambar 2. DFD Level 0 


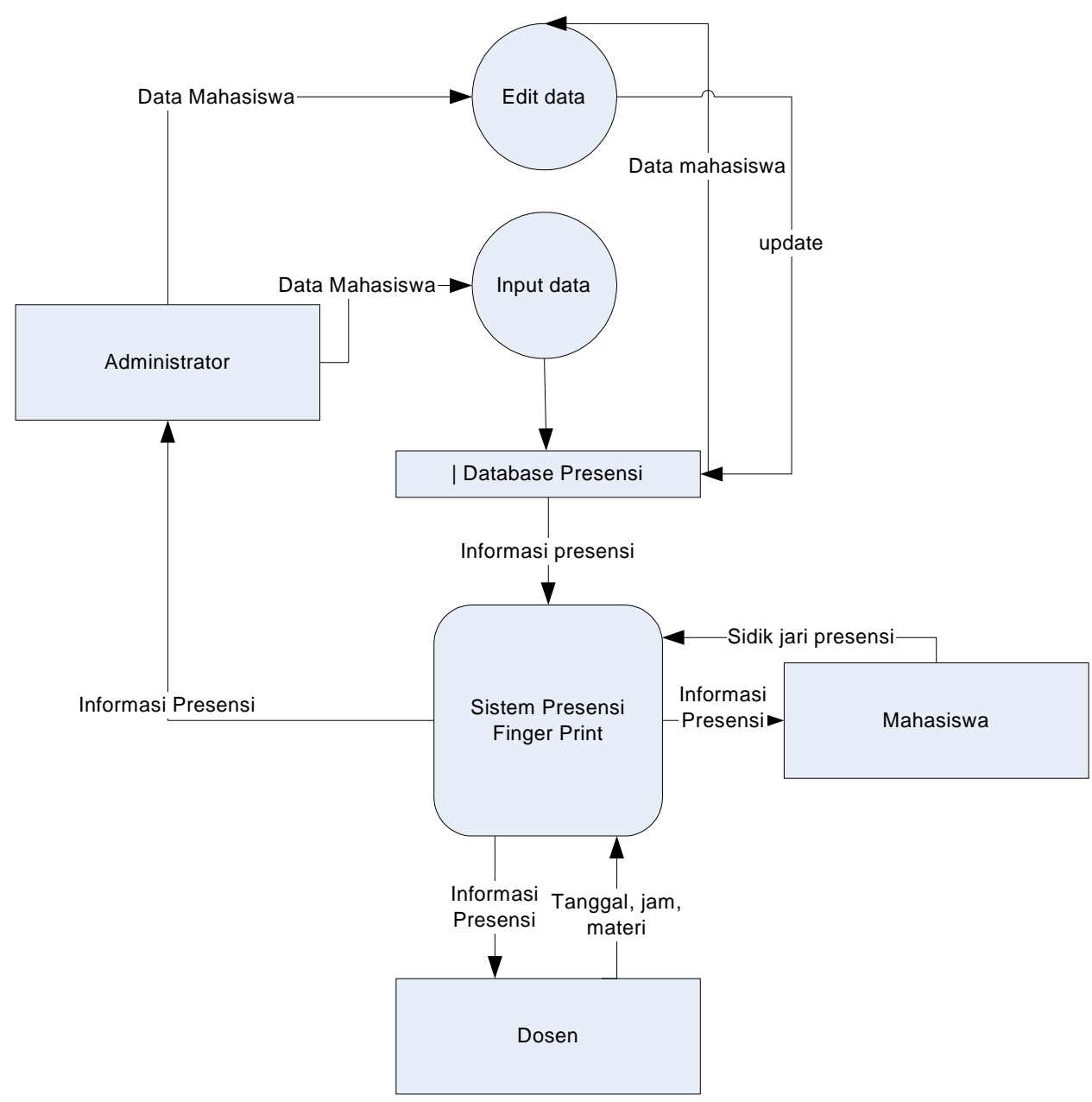

Gambar 3. DFD Level 1

\section{Kamus Data}

Tabel 1. Login

\begin{tabular}{lll}
\hline Nama field & Type & Keterangan \\
\hline username & Text (10) & Username login \\
password & Text (10) & Password login \\
\hline
\end{tabular}

Tabel 2. Mahasiswa

\begin{tabular}{lll}
\hline Nama field & Type & Keterangan \\
\hline NIM & Text (7) & $\begin{array}{l}\text { Primary key, nim } \\
\text { Mahasiswa }\end{array}$ \\
Nama & Text(50) & Nama Mahasiswa \\
$\begin{array}{l}\text { Program } \\
\text { Studi }\end{array}$ & Text (50) & Program Studi Mahasiswa \\
\hline
\end{tabular}

Tabel 3. Presensi

\begin{tabular}{lll}
\hline Nama field & Type & Keterangan \\
\hline Kode & Text (7) & $\begin{array}{l}\text { Primary Key, Kode Presensi } \\
\text { Tanggal }\end{array}$ \\
Date & $\begin{array}{l}\text { Tanggal melakukan } \\
\text { presensi }\end{array}$
\end{tabular}

$\begin{array}{lll}\text { Jam } & \text { Date } & \text { Jam melakukan presensi } \\ \begin{array}{l}\text { Kode } \\ \text { MataKuliah }\end{array} & \text { Text (6) } & \begin{array}{l}\text { Kode Mata kuliah yang } \\ \text { diajarkan } \\ \text { Materi kuliah yang } \\ \text { diajarkan }\end{array}\end{array}$

Tabel 4. Presensi 2

\begin{tabular}{lll}
\hline Nama field & Type & Keterangan \\
\hline Kode & Text (7) & Foreign Key, Kode Presensi \\
NIM & Date & NIM Mahasiswa \\
\hline
\end{tabular}

Tabel 5. Finger Print

\begin{tabular}{lll}
\hline Nama field & Type & Keterangan \\
\hline ID & $\begin{array}{l}\text { Text (10) } \\
\text { Number }\end{array}$ & Id mahasiswa berupa Nim \\
Finger & $\begin{array}{l}\text { Tipe jari yang disimpan } \\
\text { (byte) }\end{array}$ & \\
Finger Data & $\begin{array}{l}\text { OLE } \\
\text { object }\end{array}$ & \\
\hline
\end{tabular}




\section{User leveling}

\section{Administrator}

User sebagai administrator yaitu mempunyai ijin untuk mengelola semua data dan bertugas untuk melakukan input data, menghapus, dan juga melakukan presensi.

\section{Dosen (Operator)}

User sebagai operator yaitu dosen yang mempunyai ijin atau hanya diperbolehkan untuk mengakses presensi mahasiswa saja.

\section{Mahasiswa}

User sebagai mahasiswa yaitu hanya diperbolehkan untuk melakukan presensi.

\section{HASIL DAN PEMBAHASAN}

Hasil dari Rancang Bangun yang telah dilakukan adalah Sistem Presensi Mahasiswa berbasis Fingerprint Client Server yang terdiri dari 7 form utama yaitu Form Login, Form menu Utama, Form Student Registration, Form manage data, Form Fingerprint Verification, Form Get Fingerprint image, Form Presensi.

\section{Menu Login}

Menu Login pada aplikasi sistem informasi presensi menggunakan finger print ini digunakan untuk membatasi penggunaan hak akses dari aplikasi. Hak akses dalam aplikasi ini ditetapkan menjadi dua level yaitu user sebagai admin dan user sebagai operator (dosen).

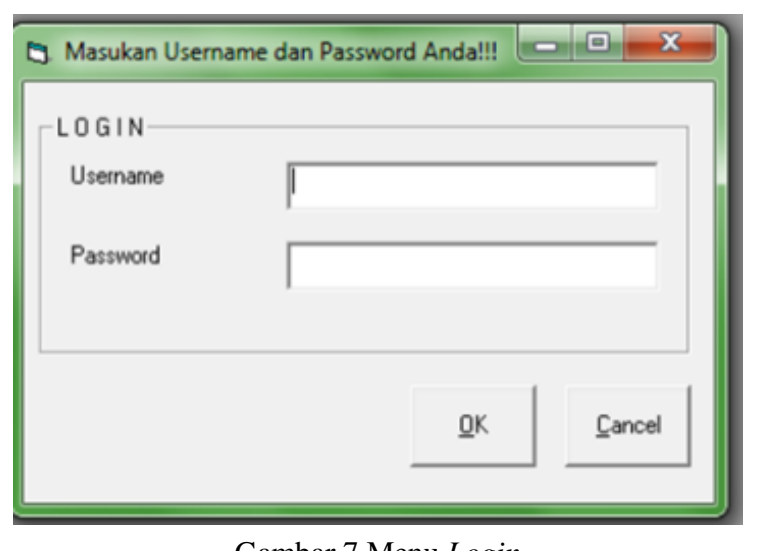

Gambar 7.Menu Login

Menu Utama Admin Dan Operator (Dosen)

Menu utama admin pada aplikasi sistem informasi presensi menggunakan finger print ini digunakan untuk memudahkan dalam pengelolaan fasilitas yang ada dalam aplikasi sistem informasi presensi menggunkan finger print.

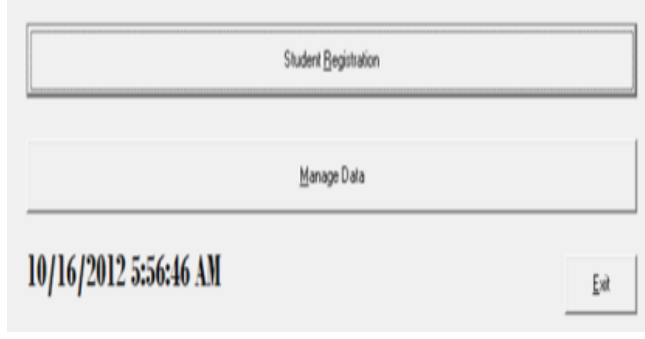

Gambar 8. Tampilan Menu Utama pada Admin

Menu Student Registration dan Manage Data Pada Admin

Menu Student Registration pada sistem informasi presensi dengan menggunakan finger print ini digunakan untuk mengelola data mahasiswa. Adapun isi tampilan dari menu Student Registration pada admin yaitu : Menu FingerprintRegistration, Fingerprint Verification, Get Fingerprint Image, Student Register dan Delete Student.

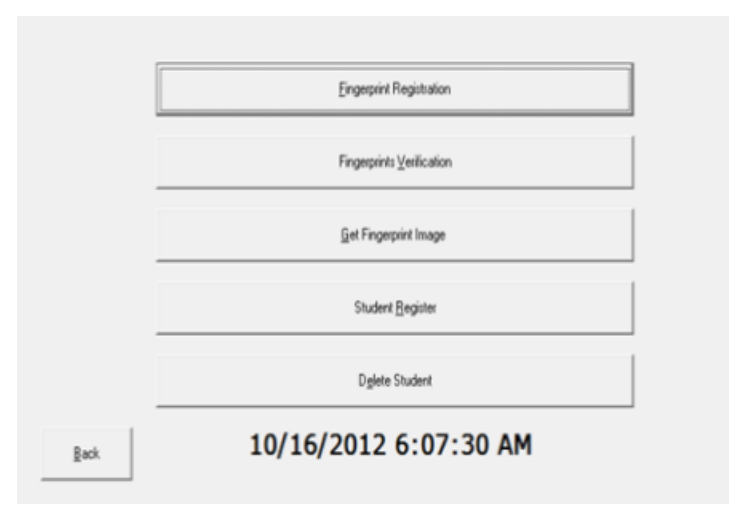

Gambar 9.Tampilan Menu Student Registration pada Admin

Sedangkan untuk menu Manage Data ini digunakan untuk mengelola data presensi mahasiswa. Adapaun isi tampilan dari menu Manage Data pada Admin yaitu : menu Presensi dan menu Find Data.

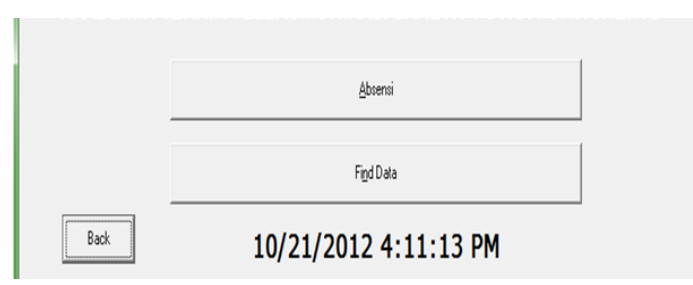

Gambar 10.Tampilan Menu Manage Data pada Admin

\section{Menu Finger Print Registration}

Menu Fingerprint Registration ini digunakan untuk input ID mahasiswa dan jenis sidik jari yang akan didaftarkan pada aplikasi sistem informasi menggunakan finger print. 


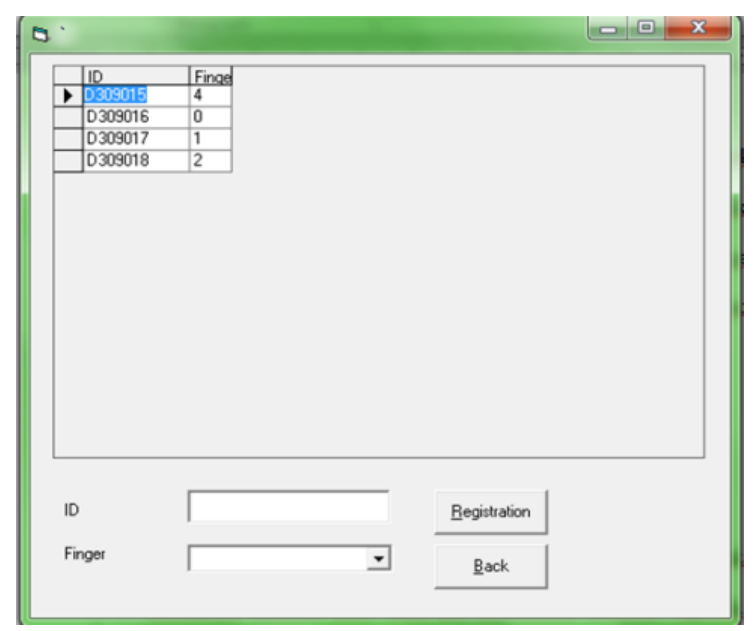

Gambar 11.Tampilan Menu Finger print Registration

\section{Menu Fingerprint Verification}

Menu Fingerprint Verification ini digunakan untuk memeriksa data sidik jari mahasiswa apakah sudah terdaftar atau belum terdaftarkan. Apabila data sidik jari mahasiswa tersebut sudah terdaftar maka hasil Result bertuliskan Match sedangakan apabila sidik jari tersebut belum terdaftar maka akan bertuliskan Not Found.

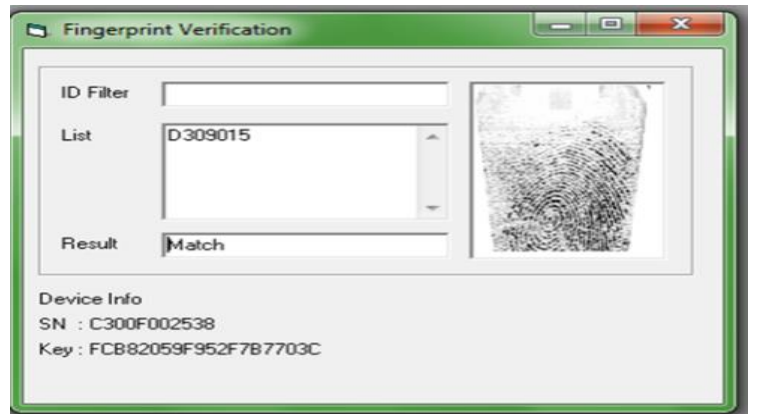

Gambar 12. Tampilan Menu Fingerprint Verification id mahasiswa sudahTerdaftar

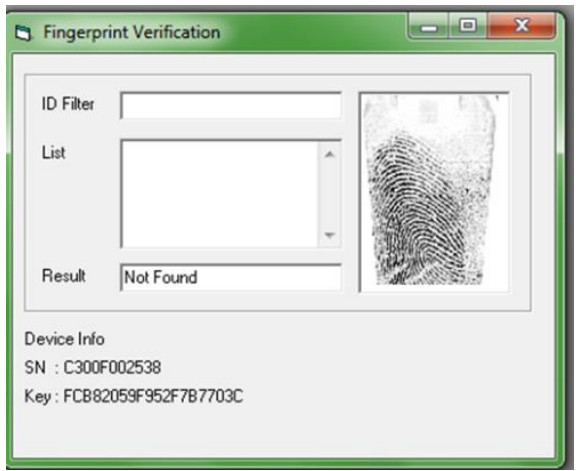

Gambar 13.Tampilan Menu Fingerprint Verification id mahasiswa belum terdaftar

\section{Menu Get Fingerprint Image}

Pada tampilan menu Get Fingerprint Image ini digunakan untuk menjadikan hasil scan sidik jari menjadi suatu gambar. Jadi file name tersebut menunjukan letak akan tersimpan data gambar sidik jari tersebut.

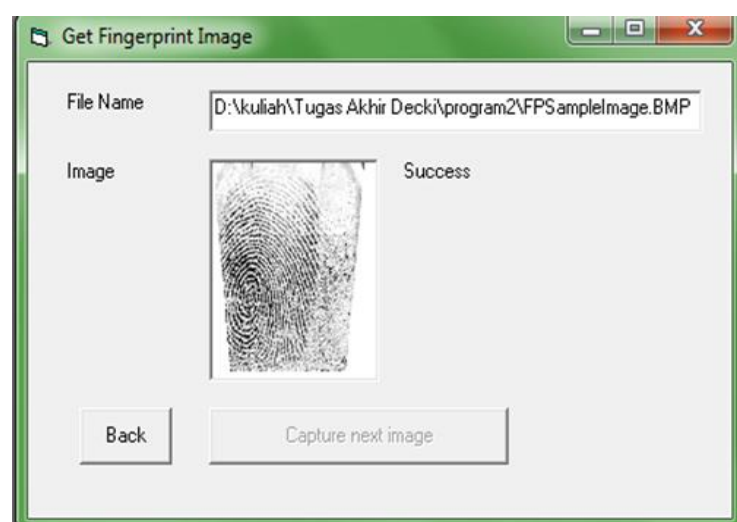

Gambar 14.Tampilan Menu Get Fingerprint Image

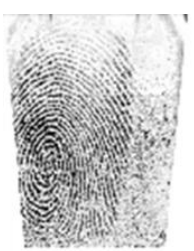

Gambar 15.Hasil Capture Image dari ScanSidik Jari

\section{Menu Student Register}

Menu Student Register ini digunakan untuk menginput data mahasiswa serta untuk mengelola data mahasiswa apabila terdapat mahasiswa baru atau mahasiswa yang belum terdaftar pada aplikasi sistem informasi menggunakan finger print.

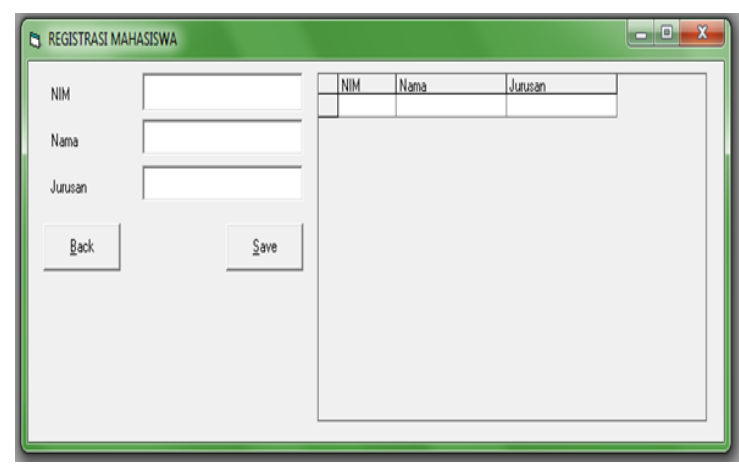

Gambar 16.Tampilan Menu Student Register

\section{Menu Delete Student}

Menu Delete Student ini digunakan untuk menghapus data mahasiswa serta untuk mengelola data mahasiswa apabila terdapat kesalahan dalam memasukkan data mahasiswa.

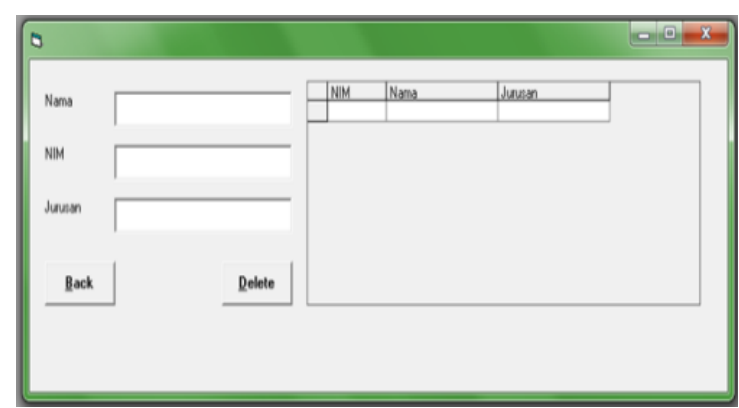

Gambar 17.Tampilan Menu Delete Student 


\section{Menu Find Data}

Menu Find Data ini digunakan untuk mencari data kehadiran mahasiswa dalam mengikuti perkuliahan, data yang terdapat pada menu Find. Data yang terdapat pada menu find data ini berupa tanggal, nim, nama, materi kuliah dan mata kuliah. Pada menu find data terdapat tombol mencari. Tombol mencari pada menu find data ini terbagi beberapa fungsi dalam pencarian data presensi mahasiswa.

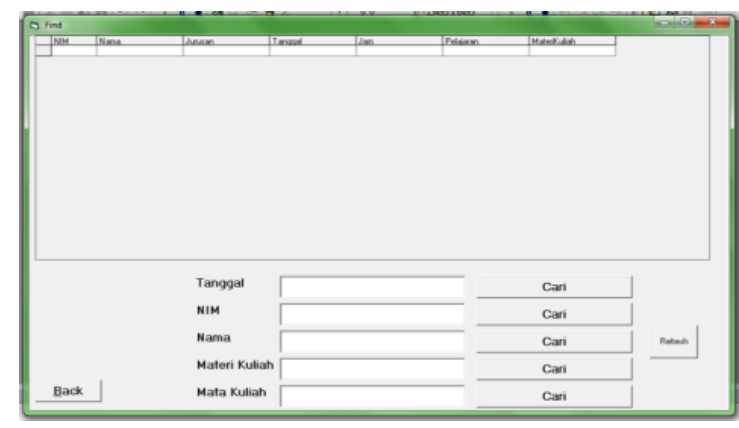

Gambar 18.Tampilan Menu Find Data

Menu Presensi Pada sisi Admin dan Operator (dosen)

Menu presensi di sisi Operator ini kegunaannya sama dengan menu presensi yang berada pada sisi admin yang digunakan untuk mencatat kehadiran data mahasiswa yang mengikuti perkuliahan. Data yang terdapat pada menu presensi yaitu berupa nim, tanggal, jam, mata kuliah dan materi kuliah. Mahasiswa melakukan presensi setelah operator (dosen) mengaktifkan menu presensi dan melakukan pemilihan mata kuliah dan materi kuliah yang akan diajarkan oleh dosen tersebut.

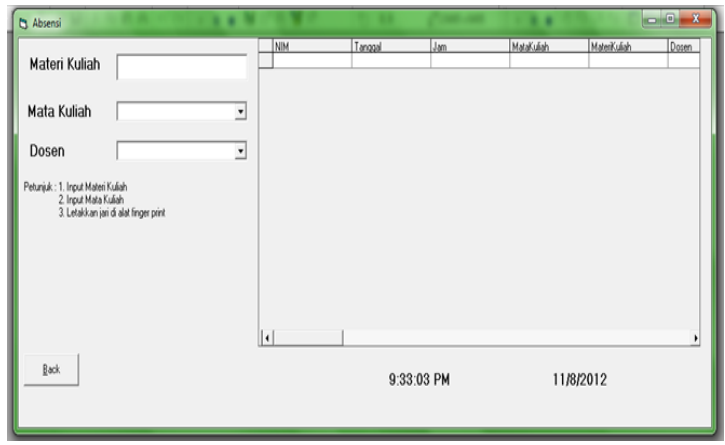

Gambar 19.Tampilan Menu Presensi

Pengujian

Pengujian sistem dilakukan dengan menggunakan Black Block Testing, dimana konsep kotak hitam digunakan untuk merepresentasikan sistem yang cara kerja di dalamnya tidak tersedia untuk diinspeksi. Pengujian ini juga disebut sebagai pengujian fungsional karena berkaitan dengan fungsi dari perangkat lunak[4].
Tabel 6. Pengujian fungsional

\begin{tabular}{|c|c|c|}
\hline No & Kebutuhan & Kesesuaian \\
\hline \multirow[t]{4}{*}{1.} & User Interface & \\
\hline & $\begin{array}{l}\text { a. Fingerprint } \\
\text { registration }\end{array}$ & Sesuai \\
\hline & $\begin{array}{l}\text { b. Fingerprint } \\
\text { verification }\end{array}$ & Sesuai \\
\hline & $\begin{array}{l}\text { c. Get Fingerprint } \\
\text { image }\end{array}$ & Sesuai \\
\hline \multirow[t]{5}{*}{2} & User Requirements & \\
\hline & a. Edit data mahasiswa & Sesuai \\
\hline & $\begin{array}{c}\text { b. Delete data } \\
\text { mahasiswa }\end{array}$ & Sesuai \\
\hline & c. Input data mahasiswa & Sesuai \\
\hline & d.Laporan presensi & Sesuai \\
\hline
\end{tabular}

\section{KESIMPULAN}

1. Rancang bangun sistem presensi mahasiswa menggunakan finger print menggunakan metode waterfall telah berhasil dibuat dengan 7 form utama.

2. Perancangan dan pembuatan sistem informasi presensi ini menggunakan Microsoft Access sebagai database, bahasa pemrograman menggunakan visual basic 6.0.

3. Pada pebuatan sistem informasi presensi ini menggunakan 3 user leveling yaitu admin operator (dosen) dan mahasiswa.

4. Dari hasil pengujian integrasi dan black box, sistem informasi presensi sudah dapat berjalan dengan baik. Output sesuai dengan rancangan yang telah dibuat

\section{DAFTAR PUSTAKA}

[1] Albab, Ulil. 2010. "Laporan Tugas Akhir Rancang Bangun Aplikasi Sistem Presensi guru dan Karyawan Menggunakan Visual Basic 6.0 dan MySQL di MTs Darul Ulum Cilacap". Akademik Teknik Telekomunikasi Sandhy Putra Purwokerto.

[2] Al Fatta, H., 2007. "Analisis Perancangan Sistem Informasi untuk keunggulan Bersaing Perusahaan dan Organisasi Modern". Andi Offset, Yogyakarta.

[3] Annymmous. 2010. "Microsoft Access 2007 Pengenalan Database Tabel Relationship Form".

http://www2.ukdw.ac.id/kuliah/info/TI2023/Modul07 A.pdf diakses tanggal 23 Juni 2012

[4] Harianto,B. 2004. "Rekayasa Sistem Berorientasi Objek". Informatika. Bandung

[5] Wadhyarini. 2010. "Analisis dan Perancangan Sistem Presisnsi Karyawan Menggunakan Sidik Jari di Aba YIPK Yokyakarta”. Sekolah Tinggi Manajemen Informatika dan Komputer Amikom Yogyakarta.

http://repository.amikom.ac.id/files/publikasi_08.21.03 79.pdf diakses pada tanggal 4 mei 2012 